\title{
Beyond ventilatory support: challenges in general practice and in the treatment of critically III children and adolescents with SARS-CoV-2 infection
}

\author{
(iD) Juliana Ferreira Ferranti ${ }^{\mathbf{1}, 2}$ \\ (iD) Isadora Souza Rodriguez ${ }^{1}$ \\ (iD) Emiliana Motta ${ }^{1}$ \\ (iD) Cintia Johnston ${ }^{3}$ \\ (D) Werther Brunow de B. Carvalho' \\ (iD) Artur Figueiredo Delgado ${ }^{1}$
}

1. Universidade de São Paulo Instituto da Criança, Unidade de Terapia Intensiva Pediátrica, São Paulo, SP, Brasil. 2. Hospital Municipal Vila Santa Catarina - Sociedade Beneficente Israelita Brasileira Albert Einstein, Unidade de Terapia Intensiva Pediátrica. 3. Fisioterapeuta/RRT, Pós-Doutorado, Instituto da Criança do Hospital das Clínicas da FMUSP, Pediatria, São Paulo, SP, Brasil.

\section{SUMMARY}

Severe acute respiratory syndrome coronavirus 2 (Sars-CoV-2 infection) is a new challenge for all countries, and children are predisposed to acquire this disease. Some studies have demonstrated more severe diseases in adults, but critically ill pediatric patients have been described in all ages. Pulmonary involvement is the major feature, and ventilatory support is common in critical cases. Nevertheless, other very important therapeutic approaches must be considered. In this article, we reviewed extensively all recent medical literature to point out the main clinical attitudes to support these pediatric patients during their period in respiratory support. Radiologic findings, fluid therapy, hemodynamic support, use of inotropic/vasopressors, nutritional therapy, antiviral therapy, corticosteroids, antithrombotic therapy, and immunoglobulins are analyzed to guide all professionals during hospitalization. We emphasize the importance of a multi-professional approach for adequate recovery.

KEYWORDS: Child. Coronavirus. Sars-CoV-2. COVID-19.

\section{INTRODUCTION}

A pneumonia case of unknown cause detected in Wuhan, China, was first reported to the WHO Country Office in China on 31 December 2019, but current case data in China reveal that children $<18$ years of age accounted for only $2.4 \%$ of all reported cases (WHO data, 2020). However, there have been multiple reports, to date, of children with asymptomatic
Sars-CoV-2 infection (Severe acute respiratory syndrome coronavirus 2). The main sources of the infection are patients infected by novel coronavirus disease (COVID-19) with or without clinical symptoms. In addition, patients in the incubation period may also $\mathrm{b}$ able to transmit the virus based on case evidence'. Since then, however, more regions around the world 
have launched pathogen detection campaigns and, since younger children cannot wear masks and no other special preventive and control measures have been taken, the number of child infection cases has increased significantly. Therefore, higher attention to this part of the population should be given. At the same time, children with other diseases (such as congenital heart, lung, and airway diseases, malnutrition, renal dysfunction, liver dysfunction, immunodeficiency, tumors, etc.) are vulnerable to infections by Sars-CoV-2 and, more specifically, predisposed to a severe clinical condition ${ }^{1,2}$.

Sars-CoV-2 originated from bats and is confirmed to be similar to Sars-CoV (Severe acute respiratory syndrome caused by Coronavirus in 2003), entering cells by binding to the angiotensin-converting enzyme 2 (ACE-2) cell receptor. According to the current data, the main routes of transmission are respiratory droplet transmission and contact transmission. It has also been reported that Sars-CoV-2 can be transmitted through aerosols, the fecal-oral route, and suspected mother-to-infant transmission, but some pediatric cases may progress to lower respiratory tract infection. Severe COVID-19 in children is rare. To date, the largest review of children with COVID-19 included 2143 children in China. Only 112 (5.6\%) of 2143 children had severe disease (defined as hypoxemia), and 13 (0.6\%) developed respiratory or multiorgan failure or pediatric acute respiratory distress syndrome (PARDS) $)^{1,3}$.

In adults, certain findings are associated with severe illness, such as high serum ferritin and bilateral abnormalities on chest CT. It is very difficult to determine common clinical characteristics in children with severe disease, and it is unclear whether there is a common biomarker due to the small number of cases $^{1,4}$.

\section{Radiologic Findings}

The chest x-ray may be normal in early or mild disease. Of all adult patients with COVID-19 requiring hospitalization, $69 \%$ had an abnormal chest radiograph at admission, and $80 \%$ had radiographic abnormalities sometime during hospitalization. Findings are more significant around 10-12 days after symptom onset. The most frequent findings are airspace opacities, whether described as consolidation or, less commonly, ground-glass opacification (GGO). The distribution is most often bilateral, peripheral, and lower-zone predominant, and pleural effusion is rare $(3 \%)^{5,6}$.
Growing evidence shows the usefulness of lung ultrasound in patients with COVID-19 and pneumonia from diagnosis, to monitoring, and follow-up. In the setting of COVID-19, wireless probe and tablets represent the most appropriate ultrasound equipment. The following patterns have been observed, with a tendency to bilateral and posterobasal predominance: multiple B-lines (ranging from focal to diffuse with spared areas, representing thickened subpleural interlobular septa); irregular, thickened pleural line with scattered discontinuities; subpleural consolidations, alveolar consolidation, restitution of aeration during recovery (reappearance of bilateral A-lines) ${ }^{5-7}$.

Unlike adult patients, only a small number of pediatric patients had multilobes affected, so we assume that children and adolescents generally have milder CT findings than adults. In adults, the findings in CT scan can be very diverse depending on high or low compliance ${ }^{8}$ : most appeared as pure GGO, GGO with consolidation, interlobular septal thickening, bronchiolar wall thickening, and asymmetric paving pattern, whereas rare manifestations included halo sign, pleural effusion, pericardial effusion, and lymphadenopathy. In a pediatric study that analyzed 6 patients, only GGO and consolidative GGO were found ${ }^{5,6,9}$.

\section{Fluid Therapy}

For the acute resuscitation of children and adolescents with COVID-19 and shock, we suggest using a conservative over a liberal fluid strategy. Buffered/ balanced crystalloids over unbalanced crystalloids can be useful with adequate metabolic and electrolyte monitoring. For the acute resuscitation of children and adolescents with COVID-19 and shock, we recommend using crystalloids over colloids. All colloids are more costly than crystalloids, and the availability of colloids is limited in some settings (e.g. some low- and middle-income countries) ${ }^{10-12}$.

One study performed by Maitland et al demonstrated that fluid boluses significantly increased 48-hour mortality in critically ill children with impaired perfusion in resource-limited settings in Africa. The results of this study challenge the importance of bolus resuscitation as a lifesaving intervention in resource-limited settings for children with shock who do not have hypotension and raise questions regarding fluid-resuscitation guidelines in other settings as well. Another study conducted the Surviving Sepsis Campaign Guidelines and did not demonstrate 
any advantages in more aggressive fluid therapy treatment in children with septic shock ${ }^{10-15}$.

One dynamic analysis during fluid therapy seems to be related to a better evolution.

\section{Hemodynamic Monitoring and Inotropic/Va-} sopressor Support

Shock can be a presentation in children with COVID-19, but the prevalence is low even in patients with severe respiratory dysfunction. Cardiac injury may correlate with the prevalence of shock and impact in the prognosis. In a study of 150 adult patients from 2 hospitals in Wuhan, China, shock was a major reason for death in $40 \%$ of the cases, which may, at least in part, be due to fulminant myocarditis. Monitoring some clinical hemodynamic non-invasive and invasive parameters is very important: skin temperature, capillary refilling time, cardiac rate, invasive arterial pressure, oximetry, capnography, pulse pressure variation, mental status, diuresis, sequential central venous pressure, central venous oxygen saturation, lactate, and cardiac index ${ }^{10,11,15}$.

Accumulating clinical data, in addition to the common clinical presentation of respiratory failure caused by COVID-19, the cardiovascular manifestations induced by this viral infection have generated considerable concern. In adults, for example, NT-proBNP elevation and arrhythmias were significantly more common in patients with elevated troponin levels, and NT-proBNP was significantly correlated with troponin levels. Special attention is necessary for patients with congenital cardiac malformation because viral illness can further damage myocardial cells through several mechanisms including direct damage by the virus and systemic inflammatory response $\mathrm{s}^{14-16}$.

For children and adolescents with COVID-19 and shock, we prefer epinephrine or norepinephrine (depending on the manifestation of hypo- or hyperdynamic shock), instead of dopamine. In the case of COVID-19 and shock with strong evidence of cardiac dysfunction and persistent hypoperfusion despite fluid resuscitation and epinephrine or norepinephrine, we suggest adding dobutamine or another inotropic agent ${ }^{15,16}$.

\section{Nutritional Therapy}

It's very important to avoid overfeeding patients with SARS-CoV-2 due to the risk of hypercapnia. In adults, $50.5 \%$ of patients reported a digestive symptom, including: lack of appetite (81 [78.6\%] cases), diarrhea (35 [34\%] cases), vomiting (4 [3.9\%] cases), and abdominal pain (2 [1.9\%] cases). Altered digestive process and malabsorption can occur, and special diets (oligomeric without lactose) may be necessary. We also need to bear in mind that viruses can persist in feces long after they are absent from nasopharyngeal secretions. It has been found that ACE2 is not only expressed in lung Alveolar type 2 progenitor cells (AT2 cells), but also in upper esophageal and stratified epithelial cells, as well as intestinal epithelial cells in the ileum and colon. Therefore, intestinal symptoms of SARS-CoV-2 may be associated with the invasion of intestinal epithelial cells. Another study in adult patients with SARS-CoV-2 infection who were transferred to the intensive care unit found a higher frequency of abdominal pain in these patients than in those with SARS-CoV-2 infection who did not require intensive care, and $10 \%$ of patients with COVID-19 experienced diarrhea and nausea symptoms ${ }^{17,18}$.

In critically ill patients with SARS-CoV-2 infection and severe pulmonary injury, avoiding gastroesophageal reflux in consequence of excessive gastric distention is a major attitude. The gastric administration of the diet is preferred to optimize digestive activity but in the case of failure, we suggest the postpyloric via (jejunal preferably) ${ }^{17,18}$.

Nutritional treatment recommendations to date are based on observations, rather than evidence from clinical trials.

\section{Drug Therapy}

Since the COVID-19 outbreak in December 2019, doctors around the world have faced several challenges in the management of COVID-19 patients. One of them is the choice of adequate therapy,19-21. A wide range of medications is being studied for the management of these patients; however, none of them has been established as the gold standard yet. Supportive therapy, like the ones cited previously in this article, are still the mainstay in the management of COVID-19 patients ${ }^{1,20}$. Since there are no specific antiviral agents against Sars-CoV-2, multiple pharmacologic agents are being tested, some of them such as anti-viral agents, antimalarial drugs, corticosteroids, intravenous immunoglobulin, and selective cytokine blockers, such as anakinra or tocilizumab $b^{1,22-25}$. Among these options, one available choice is using a broad-spectrum antiviral drug like nucleoside analogs and HIV-protease inhibitors that could attenuate virus infection ${ }^{26}$. Besides antiviral agents, antimalarial 
drugs have also been tested with apparently positive results ${ }^{27}$. In children, until now, no antiviral therapeutic agent is recommended and the only treatment recommendation described suggests the use of nebulized interferon-alpha- $2 b^{20,28}$.

Given the multiple treatment options, we chose to unravel the drugs that seem more promising and the various studies that have been conducted. Most of these studies have been carried out in adult populations since children seem to have a milder clinical course, with multiple, but still unknown, possible reasons ${ }^{1,20,29-32}$. One suggested reason is that children may be less susceptible to the infection as a result of possible differences in the expression of the angiotensin-converting enzyme 2 (ACE2) ${ }^{24,25,32}$. Despite that, the importance of children in virus transmission remains uncertain. If bacterial coinfection is suspected, antibiotic therapy must be timely initiated ${ }^{1,20}$.

Antimalarial agents, such as chloroquine and its derivative, hydroxychloroquine, potential antiviral drugs, have shown positive results during in vitro testing against SARS-CoV-2 and in some clinical studies with COVID 19 adult patients ${ }^{27,33,34}$. Chloroquine blocks viral entry to endosomes by increasing their $\mathrm{pH}$, inhibiting the replication and spread of SARS-CoV-2 ${ }^{33,34}$. The immunomodulant effect of chloroquine may enhance the antiviral effect in vivo ${ }^{23,26,27,33}$. The low cost and safety profile of chloroquine are major benefits for its use in the healthcare system; however, this is still a topic for debate.

The use of lopinavir and ritonavir, both antiviral drugs, is being discussed as a treatment option against Sars-CoV-2 $26,33,35$. One study conducted in Hong Kong showed benefits in SARS patients treated with lopinavir/ritonavir and ribavirin when compared with only ribavirin $^{36,37}$. However, a recent open-label trial with 199 patients conducted in China found no benefits in the lopinavir/ritonavir group and had more adverse events with the use of the medication ${ }^{38}$. Another retrospective study did not observe the shortening of viral shedding duration after lopinavir/ritonavir treatment ${ }^{39}$. Further studies are necessary to establish the real role of this medication in the Sars-CoV-2 treatment, especially in the pediatric population.

\section{Corticosteroids}

Infection by Sars-CoV-2 can induce an important inflammatory response and provoke the release of cytokines, therefore corticosteroid use for the treatment of patients with severe illness was an option since they can reduce the inflammatory-induced lung injury $^{23}$. Despite that, posterior evidence suggested that corticosteroids did not affect mortality. Instead of this desired result, corticosteroids delayed viral clearance. So, in the meantime, the use of corticosteroids should not be routine ${ }^{40}$.

Notwithstanding the evidence against the use of corticosteroid, in some clinical situations, they are beneficial, such as PARDS, encephalitis, hemophagocytic syndrome, or septic shock and asthma patients, 1,10,22,32.

\section{Coagulopathy and Antithrombotic Therapy}

To date, there is no literature regarding anticoagulation in COVID-19 patients in the pediatric population. All information comes from adult studies ${ }^{41-43}$.

In adult patients with COVID-19, two recent retrospective studies have shown that the existence of disseminated intravascular coagulation is common in nonsurvivors, with abnormal coagulation results, in particular elevated D-dimer and fibrin degradation product ${ }^{42,44,45}$. This information may help guide therapy and evaluate prognosis. Besides these results, a recent article reported that occlusion and microthrombosis formation in pulmonary small vessels occurred in one critical patient with COVID-19 after lung organ dissection ${ }^{46}$. A recently published study demonstrated that anticoagulant therapy seems to be associated with better prognosis in severe COVID-19 patients, especially those with markedly elevated D-dimer ${ }^{47}$.

Considering the risk for venous thromboembolism in patients with severe COVID-19, expert consensus in China and by the International Society of Thrombosis and Haemostasis recommend a prophylactic dose of low molecular weight heparin to all COVID-19 patients who require hospital admission, in the absence of any contraindications ${ }^{47-49}$. It is also recommended the therapeutic administration of heparin in cases of pro-thrombotic conditions. Unfortunately, until the time of this publication, there are no data that support its use in children.

\section{Plasma / Immunoglobulins}

No specific treatment has been proven to be effective for Sars-CoV-2, and specific drugs have been researched. Convalescent plasma or immunoglobulins have been used as an empirical treatment during the Ebola virus outbreak in 2014 and in the Middle East respiratory syndrome coronavirus in 2015. In patients with pandemic 2009 influenza A H1N1 virus infection (H1N1pmd09), there was a reduction in the relative 
risk of mortality and no adverse events were observed. Therefore, the use of convalescent plasma transfusion could be beneficial in patients with SARS-CoV-2. The plasma is donated from recovered SARS-CoV-2 patients that may have a high level of antibodies ${ }^{47-50}$. Recently, Shen et al. ${ }^{47}$ described a case series of 5 patients with severe disease, rapid progression, and refractory hypoxemia. They were treated with plasma and their clinical condition improved, as did their body temperature, $\mathrm{PaO} 2 / \mathrm{FiO} 2$ ratio, and chest imaging ${ }^{51}$. A study performed by Zhang et al. ${ }^{50}$ showed no serious adverse reactions associated with the transfusion of convalescent plasma in four critically ill patients infected with SARS-CoV-2. The risks of convalescent plasma administration are associated with the transfer of blood substances, which include infections and immunological reactions to serum constituents. The
Surviving Sepsis Campaign guideline of COVID-19 suggests against the routine use of standard intravenous immunoglobulin (IVIG) and the routine use of convalescent plasma because poor efficacy data are available and more evidence is necessary ${ }^{10}$. The FDA (US Food and Drug Administration) has approved the use of plasma from recovered patients to treat people who are critically ill with COVID- $19^{51}$. Therefore, therapy with convalescent plasma may be considered within the context of a well-designed clinical trial.

\section{Physiotherapy during COVID-19}

It's very important to have adequate management of the physiotherapy team considering the following aspects: avoid or minimize movement of professionals during work shifts; encourage psychological assistance programs to the entire team in consequence of

TABLE 1. INTERVENTIONS INVOLVING THE PARTICIPATION OF A PHYSICAL THERAPIST

\begin{tabular}{|c|c|c|c|}
\hline $\begin{array}{l}\text { INTERVENTIONS INVOLVING } \\
\text { THE PARTICIPATION OF A } \\
\text { PHYSICAL THERAPIST }\end{array}$ & MODERATE INFECTION & SEVERE INFECTION & CRITICAL INFECTION \\
\hline $\begin{array}{l}\text { Removal of airway secretion } \\
\text { (upper and/or lower) }\end{array}$ & If secretion present in airway & YES & YES \\
\hline Pulmonary Reexpansion & If atelectasis & If atelectasis & YES \\
\hline Prone Position & Not applicable & YES & YES \\
\hline Early mobilization & $\begin{array}{l}\text { If comorbidities and/or immobili- } \\
\text { zation syndrome }\end{array}$ & YES & NO \\
\hline $\begin{array}{l}\text { Mobilization/Exercises } \\
\text { (passive and/or active-assisted) }\end{array}$ & $\begin{array}{l}\text { If comorbidities and/or immobili- } \\
\text { zation syndrome }\end{array}$ & YES & YES \\
\hline $\begin{array}{l}\text { Low flow oxigen } \\
\text { (uo to } 6 \mathrm{~L} / \mathrm{min} \text { ) }\end{array}$ & YES & NO & Not applicable \\
\hline $\begin{array}{l}\text { High Flow Nasal Oxegen therapy } \\
\text { (HFNO) }\end{array}$ & $\begin{array}{l}\text { If in negative pressure ward } \\
\text { (or ventilated isolation ward) + } \\
\text { indicated PPEs }\end{array}$ & NO & Not applicable \\
\hline Non-Invasive Ventilation (NIV) & $\begin{array}{l}\text { If in negative pressure ward } \\
\text { (or ventilated isolation ward) + } \\
\text { indicated PPEs }\end{array}$ & $\begin{array}{l}\text { If in negative pressure ward } \\
\text { (or ventilated isolation ward) + } \\
\text { indicated PPEs }\end{array}$ & Not applicable \\
\hline Cuff-pressure monitoring & $\begin{array}{l}\text { YES, if patitent with tracheos- } \\
\text { tomy }\end{array}$ & $\begin{array}{l}\text { YES, if tracheostomy or intubated } \\
\text { patient }\end{array}$ & YES \\
\hline Bag-mask ventilation & NO & NO & $\begin{array}{l}\text { YES, if bacterial filter use in a bag } \\
\text { and/or acrylic box }\end{array}$ \\
\hline Manual Hiperinsuflation & NO & NO & $\begin{array}{l}\text { YES, if bacterial filter use in a bag } \\
\text { and/or acrylic box }\end{array}$ \\
\hline Respiratory mechanic monitoring & $\begin{array}{l}\text { If in NIV or chronic ventilated } \\
\text { patient }\end{array}$ & YES & YES \\
\hline Inhaled nitric oxide (Noi) & Not applicable & NO & YES \\
\hline HFOV / HFV & Not applicable & Not applicable & Not applicable \\
\hline Endotracheal intubation & NO & May be necessary & YES \\
\hline Extubation & NO & May be necessary & YES, when clinically stable \\
\hline Unplanned extubation & Not applicable & May occur & May occur \\
\hline Airway aspiration & May be necessary & YES & YES \\
\hline
\end{tabular}

OBS: in asymptomatic cases or cases with mild COVID-19 infection there is no need for a physical therapist in the hospital environment; it is understood as "not applicable" when there is no scientific evidence and/or clinical report of the benefits of the conduct; it is understood as YES when the conduct can be applied in pediatrics and includes the performance of a Physiotherapist; it is understood as NO when the conduct is not applied in pediatrics and/or does not require the participation of a Physiotherapist. LEGEND: $\mathrm{NIV}=$ non-invasive ventilation; HFOV = high frequency oscillatory ventilation; HFV = high frequency ventilation due to flow interruption; Noi = inhaled nitric oxide; PPE = personal protective equipment. 
the high risk of Burnout (state of emotional, physical, and mental exhaustion caused by excessive and prolonged stress) $)^{52}$.

We recommend guiding and instructing all awake patients to cough correctly during physiotherapy procedures: when coughing or sneezing, cover the mouth and nose with the forearm or a handkerchief, which should be immediately discarded. Then wash hands with soap and water or $70 \%$ gel alcohol ${ }^{52}$.

The interventions that include the participation of a physical therapist are listed in table 1 and must consider the severity of the disease infection for the indication or not of the procedures.

\section{CONCLUSIONS}

The Sars-CoV-2 infection is a new challenge for all healthcare professionals. In children and adolescents, frequently, the disease is milder in clinical and radiologic aspects if compared to adults, but critically ill pediatric patients have been described in all ages.
Several approaches as important as respiratory support must be considered. The analysis of radiologic findings, adequate fluid therapy, hemodynamic support, early nutritional therapy, and physiotherapy are essential during treatment. Other therapeutics (corticosteroids, antiviral therapy, antithrombotic therapy, and use of immunoglobulins) are controversial but can be useful after solid investigation. We emphasize the importance of a multi-professional approach for adequate recovery.

\section{Acknowledgments}

We would like to thank Dr. Jorge David Aivazoglou Carneiro

\section{Authors Contribuition}

Juliana Ferreira Ferranti; Isadora Souza Rodriguez; Emiliana Motta; Cíntia Johnston; Werther Brunow de B Carvalho; Artur Figueiredo Delgado - Contribution: bibliographic survey, design, critical analysis, writing and agreement on the conclusions.

\section{RESUMO}

A síndrome respiratória aguda grave (SRAG) pelo novo coronavirus (SARS-CoV-2) é um novo desafio para todos os países e crianças estão predispostas a adquirir a doença. Alguns estudos demonstraram quadros mais graves em adultos, mas crianças criticamente doentes foram descritas em todas as idades. O envolvimento pulmonar é a principal característica e a necessidade de suporte ventilatório é comum nos casos mais graves. Entretanto, outras abordagens terapêuticas importantes devem ser consideradas. Nesse artigo revisamos extensamente a literature médica até o momento a fim de citar os principais recursos terapêuticos para o manejo dos pacientes pediátricos durante o período de suporte ventilatório. Achados radiológicos, terapia fluídica, terapia antiviral, o uso de corticosteroides, terapia antitrombótica e o uso de imunoglobulinas foram analisados a fim de guiar os profissionais durante o período de hospitalização desses pacientes. Nós reforçamos a importância de uma abordagem multiprofissional para recuperação adequada.

PALAVRAS-CHAVE: Criança. Coronavirus. SARS-CoV-2. COVID-19.

\section{REFERENCES}

1. Chen ZM, Fu JF, Shu Q, Chen YH, Hua CZ, Li FB, et al. Diagnosis and treatment recommendations for pediatric respiratory infection caused by the 2019 novel coronavirus. World J Pediatr. 2020. doi: 10.1007/ s12519-020-00345-5.

2. Chan JF, Yuan S, Kok KH, To KK, Chu H, Yang J, et al. A familial cluster of pneumonia associated with the 2019 novel coronavirus indicating person-to-person transmission: a study of a family cluster. Lancet. 2020;395(10223):514-23.

3. Li Y, Guo F, Cao Y, Li L, Guo Y. Insight into COVID-2019 for pediatricians. Pediatr Pulmonol. 2020;55(5):E1-E4.

4. Huang C, Wang Y, Li X, Ren L, Zhao J, Hu Y, et al. Clinical features of patients infected with 2019 novel coronavirus in Wuhan, China. Lancet. 2020;395(10223):497-506.

5. Pan F, Ye T, Sun P, Gui S, Liang B, Li L, et al. Time course of lung changes on chest CT during recovery from 2019 novel coronavirus (COVID-19) pneumonia. Radiology. 2020:200370. doi: 10.1148/radiol.2020200370.

6. Song F, Shi N, Shan F, Zhang Z, Shen J, Lu H, et al. Emerging 2019 Novel coronavirus (2019-nCoV) pneumonia. Radiology. 2020;295(1):210-7.
7. Soldati G, Smargiassi A, Inchingolo R, Buonsenso D, Perrone T, Briganti $D F$, et al. Proposal for international standardization of the use of lung ultrasound for COVID-19 patients; a simple, quantitative, reproducible method. J Ultrasound Med. 2020. doi: 10.1002/jum.15285.

8. Gattinoni L, Chiumello D, Caironi P, Busana M, Romitti F, Brazzi L, et al. COVID-19 pneumonia: different respiratory treatments for different phenotypes? Intensive Care Med. 2020. DOI: 10.1007/s00134-020-06033-2

9. Liu M, Song Z, Xiao K. High-resolution computed tomography manifestations of 5 pediatric patients with 2019 novel coronavirus. J Comput Assist Tomogr. 2020. doi: 10.1097/RCT.0000000000001023.

10. Alhazzani W, Møller MH, Arabi YM, Loeb M, Gong MN, Fan E, et al. Surviving Sepsis Campaign: guidelines on the management of critically ill adults with coronavirus disease 2019 (COVID-19). Intensive Care Med. 2020. doi: 10.1007/s00134-020-06022-5

11. Coopersmith CM, De Backer D, Deutschman CS, Ferrer R, Lat I, Machado FR, et al. Surviving Sepsis Campaign: research priorities for sepsis and septic shock. Crit Care Med. 2018;46(8):1334-56. 
12. Medeiros DN, Ferranti JF, Delgado AF, Carvalho WB. Colloids for the initial management of severe sepsis and septic shock in pediatric patients: a systematic review. Pediatr Emerg Care. 2015;31(11):e11-6.

13. Maitland K, Kiguli S, Opoka RO, Engoru C, Olupot-Olupot P, Akech SO, et al., FEAST Trial Group. Mortality after fluid bolus in African children with severe infection. N Engl J Med. 2011;364(26):2483-95.

14. Workman JK, Ames SG, Reeder RW, Korgenski EK, Masotti SM, Bratton SL, et al. Treatment of pediatric septic shock with the Surviving Sepsis Campaign guidelines and PICU patient outcomes. Pediatr Crit Care Med. 2016;17(10):e451-8.

15. Dellinger RP, Levy MM, Rhodes A, Annane D, Gerlach H, Opal SM, et al; Surviving Sepsis Campaign Guidelines Committee including the pediatric subgroup: surviving sepsis campaign: international guidelines for management of severe sepsis and septic shock: 2012. Crit Care Med. 2013;41(2):580-637.

16. Guo T, Fan Y, Chen M, Wu X, Zhang L, He T, et al. Cardiovascular implications of fatal outcomes of patients with coronavirus disease 2019 (COVID19). JAMA Cardiol. 2020. doi: 10.1001/jamacardio.2020.1017.

17. Gao QY, Chen YX, Fang JY. 2019 Novel coronavirus infection and gastrointestinal tract. J Dig Dis. 2020;21(3):125-6.

18. Zamberlan P, Delgado AF, Leone C, Feferbaum R, Okay TS. Nutrition therapy in a pediatric intensive care unit: indications, monitoring, and complications. JPEN J Parenter Enteral Nutr. 2011;35(4):523-9.

19. Zhu N, Zhang D, Wang W, Li X, Yang B, Song J, et al; China Novel Coronavirus Investigating and Research Team. A novel coronavirus from patients with pneumonia in China, 2019. N Engl J Med. 2020;382(8):727-33.

20. Zimmermann $P$, Curtis N. Coronavirus infections in children including COVID-19: an overview of the epidemiology, clinical features, diagnosis, treatment and prevention options in children. Pediatr Infect Dis J. 2020. doi: 10.1097/INF.0000000000002660

21. Rasmussen SA, Thompson LA. Coronavirus disease 2019 and children: what pediatric health care clinicians need to know. JAMA Pediatr. 2020. doi: 10.1001/jamapediatrics.2020.1224.

22. Hong $\mathrm{H}$, Wang $\mathrm{Y}$, Chung $\mathrm{HT}$, Chen $\mathrm{C}$ ). Clinical characteristics of novel coronavirus disease 2019 (COVID-19) in newborns, infants and children. Pediatr Neonatol. 2020;61(2):131-2

23. Molloy EJ, Bearer CF. COVID-19 in children and altered inflammatory responses. Pediatr Res. 2020. doi: 10.1038/s41390-020-0881-y.

24. Ong JSM, Tosoni A, Kim Y, Kissoon N, Murthy S. Coronavirus disease 2019 in critically ill children: a narrative review of the literature. Pediatric Crit Care Med. 2020. doi: 10.1097/PCC.0000000000002376.

25. Tang A, Xu W, Shen M, Chen P, Li G, Liu Y, et al. A retrospective study of the clinical characteristics of COVID-19 infection in 26 children. medRxiv. 2020. doi:https://doi.org/10.1101/2020.03.08.20029710.

26. Rothan HA, Byrareddy SN, The epidemiology and pathogenesis of coronavirus disease (COVID-19) outbreak. J Autoimmun. 2020;109:102433.

27. Cortegiani A, Ingoglia G, Ippolito M, Giarratano A, Einav S. A systematic review on the efficacy and safety of chloroquine for the treatment of COVID-19. J Crit Care. 2020. doi: 10.1016/j.jcrc.2020.03.005.

28. Wang Y, Zhu LQ. Pharmaceutical care recommendations for antiviral treatments in children with coronavirus disease 2019. World J Pediatr. 2020. doi: 10.1007/s12519-020-00353-5.

29. Lu X, Zhang L, Du H, Zhang J, Li YY, Qu J, et al; Chinese Pediatric Novel Coronavirus Study Team. SARS-CoV-2 infection in children. N Engl J Med. 2020. doi: 10.1056/NEJMc2005073.

30. Hasan A, Mehmood N, Fergie I. Coronavirus disease (COVID-19) and pediatric patients: a review of epidemiology, symptomatology, laboratory and imaging results to guide the development of a management algorithm. Cureus. 2020;12(3):e7485.
31. Wei M, Yuan J, Liu Y, Fu T, Yu X, Zhang Z). Novel coronavirus infection in hospitalized infants under 1 year of age in China. JAMA. 2020. doi: 10.1001/ jama.2020.2131.

32. Lee PI, Hu YL, Chen PY, Huang YC, Hsueh PR. Are children less susceptible to COVID-19? J Microbiol Immunol Infect. 2020. doi: 10.1016/j. jmii.2020.02.011.

33. Gao J, Tian Z, Yang X. Breakthrough: Chloroquine phosphate has shown apparent efficacy in treatment of COVID-19 associated pneumonia in clinical studies. Biosci Trends. 2020;14(1):72-3.

34. Chen Z, Hu J, Zhang Z, Jiang S, Han S, Yan D, et al. Efficacy of hydroxychloroquine in patients with COVID-19: results of a randomized clinical trial. medRxiv. 2020. doi: https://doi.org/10.1101/2020.03.22.20040758.

35. Carlotti APCP, Carvalho WB, Johnston C, Rodriguez IS, Delgado AF. COVID19 Diagnostic and management protocol for pediatric patients. Clinics. 2020;75:e1894

36. Lu H. Drug treatment options for the 2019-new coronavirus (2019-nCoV). Biosci Trends. 2020;14(1):69-71.

37. Chu CM, Cheng VC, Hung IF, Wong MM, Chan KH, Chan KS, et al; HKU/ UCH SARS Study Group. Role of lopinavir/ritonavir in the treatment of SARS: initial virological and clinical findings. Thorax. 2004;59(3):252-6.

38. Cao B, Wang Y, Wen D, Liu W, Wang J, Fan G, et al. A trial of lopinavirritonavir in adults hospitalized with severe COVID-19. New Engl | Med. 2020. doi: 10.1056/NEJMoa2001282.

39. Zhou F, Yu T, Du R, Fan G, Liu Y, Liu Z, et al. Clinical course and risk factors for mortality of adult inpatients with COVID-19 in Wuhan, China: a retrospective cohort study. Lancet. 2020;395(10229):1054-62.

40. Bouadma L, Lescure FX, Lucet JC, Yazdanpanah Y, Timsit JF. Severe SARSCoV-2 infections: practical considerations and management strategy for intensivists. Intensive Care Med. 2020;46(4):579-82.

41. Tang N, Li D, Wang X, Sun Z. Abnormal coagulation parameters are associated with poor prognosis in patients with novel coronavirus pneumonia. J Thromb Haemost. 2020;18(4):844-7.

42. Lillicrap D. Disseminated intravascular coagulation in patients with 2019nCoV pneumonia. J Thromb Haemost. 2020;18(4):786-7.

43. Luo W, Yu H, Gou J, Li X, Sun Y, Li J, et al. Clinical pathology of critical patient with novel coronavirus pneumonia (COVID-19). Preprints. 2020, 2020020407.

44. Tang N, Bai H, Chen X, Gong J, Li D, Sun Z. Anticoagulant treatment is associated with decreased mortality in severe coronavirus disease 2019 patients with coagulopathy. J Thromb Haemost. 2020. doi: 10.1111/jth.14817.

45. Thachil J. The versatile heparin in COVID-19. J Thromb Haemost. 2020. doi: 10.1111/jth.14821.

46. Thachil J, Tang N, Gando S, Falanga A, Cattaneo M, Levi M, et al. ISTH interim guidance on recognition and management of coagulopathy in COVID-19. J Thromb Haemost. 2020. doi:10.1111/jth.14810

47. Shen C, Wang Z, Zhao F, Yang Y, Li J, Yuan J, et al. Treatment of 5 critically ill patients with COVID-19 with convalescent plasma. JAMA. 2020. doi: 10.1001/jama.2020.4783.

48. Chen L, Xiong J, Bao L, Shi Y. Convalescent plasma as a potential therapy for COVID-19. Lancet Infect Dis. 2020;20(4):398-400.

49. Casadevall A, Pirofski LA. The convalescent sera option for containing COVID-19. J Clin Invest. 2020;130(4):1545-8.

50. Zhang B, Liu S, Tan T, Huang W, Dong Y, Chen L, et al. Treatment with convalescent plasma for critically ill patients with SARS-CoV-2 infection. Chest. 2020. doi: 10.1016/j.chest.2020.03.039.

51. Tanne JK. COVID-19: FDA approves use of convalescent plasma to treat critically ill patients. BMJ. 2020;368:m1256.

52. Thomas $P$, Baldwin C, Bissett $B$, Boden I, Gosselink R, Granger CL, et al. Physiotherapy management for COVID-19 in the acute hospital setting: clinical practice recommendations. I Physiotherapy. 2020; Mar 26. DOI: 10.1016/J.phys.2020.03.011 